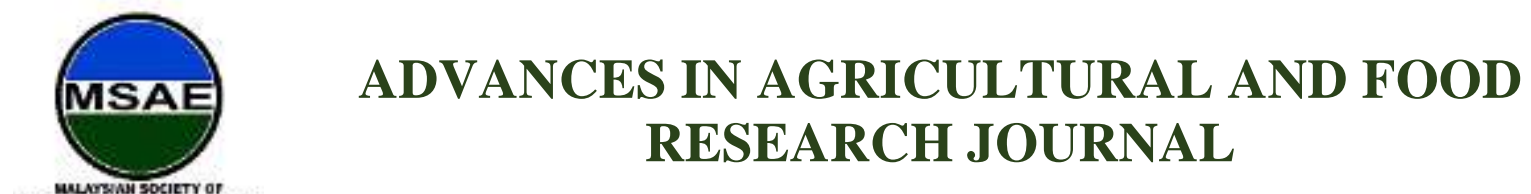

Original Research Article

\title{
A Study on Hybrid Power Vehicle for Electric Spraying Application
}

\author{
Azwan M.B. ${ }^{1 *}$, Salmah J. ${ }^{1}$, Abd Rahim S. ${ }^{1}$, Syazwan R. ${ }^{1}$, M. Ikmal H. ${ }^{1}$ \\ ${ }^{1}$ Mechanisation and Engineering Unit, Malaysia Palm Oil Board, Jln Sekolah, Pekan Bangi Lama, 43000 \\ Kajang, Selangor, Malaysia. \\ **Corresponding author: Azwan M.B., Mechanisation and Engineering Unit, Malaysia Palm Oil Board, Jln
Sekolah, Pekan Bangi Lama, 43000 Kajang, Selangor, Malaysia; azwan.bakri@ mpob.gov.my
}

\begin{abstract}
Agriculture currently relies more on fossil fuel power for its mechanised operation. However, the electric power system embedded in agriculture machinery enables farm electrification that provides numerous advantages such as improve work efficiency, ease of equipment control, reduce energy requirement and more ergonomic. This study aims to analyse a hybrid power farm vehicle configuration to enable the electrification of farm operation such as herbicide spraying. Two methodologies are presented for this study, which are simulation analysis and in-field test validation. HOMER software indicates that fraction of energy for herbicide spraying operation and charging the battery pack is $70 \%$ from solar energy and $30 \%$ from the rectifier engine output. The $20 \mathrm{~W}$ att solar photovoltaic is selected due to installation area constraint on the farm utility vehicle, and simulation results indicate the capacity is adequate for the intended purpose. Besides that, the simulation results also show the setup incurs lower energy cost up to $30 \%$ as compared to direct utilisation of the fossil fuel generator for the herbicide spraying. The in-field test study has validated the simulation results. The analysis indicates that the battery performance is consistent throughout the trial for almost two months of operation at the area which covers nearly 150ha. The productivity of the machine obtained through the test is on average of 8ha per day for a single man operation. In conclusion, the study shows that incorporation of solar power as opportunity charging could stabilise battery condition and will prolong battery health. The results also indicate that electrification of the farm equipment and its application could bring the desired positive result in farm activity. Thus, a more sustainable development approach to agriculture practice could be met.
\end{abstract}

Keywords: Oil palm mechanisation; hybrid power vehicle; energy in agriculture production; sustainability; solar photovoltaic; herbicide spraying

Received: $18^{\text {th }}$ May 2020

Accepted: $14^{\text {th }}$ August 2020

Published: $2^{\text {nd }}$ September 2020

Citation: Azwan MB, Salmah J, Abd Rahim $\mathrm{S}$, et al. A study on hybrid power vehicle for electric spraying application. Adv Agri Food Res J 2020; 1(1): a0000103. https://doi.org/10.36877/aafri.a0000103 


\section{Introduction}

Electric farm tools and implements provide a lot of advantages in terms of controllability, higher efficiency distribution, easy installation and fuel saving. The advancement of a mechatronic technology enables the application of electric equipment in the agriculture sector that could lead to more advanced agriculture practice, such as automation and robotics use (Kushairi, Singh \& Ong-Abdullah, 2017). Several studies had indicated better performance of the electrification of farm implements towards the agriculture practices (Abdelhamid $e t$ al., 2018; Blackmore, Wang \& Runov, 2005; Somà, 2017). The method of farm tool's electrification is realised by integrating the vehicle or tractor power system either alternating current (AC) or direct current (DC) architecture to electric power implements such as fertiliser spreader, chemical sprayer or other tools.

The farm electrification is much dependent on the requirement of the agriculture application and selection of the vehicle to provide the energy. The condition also depends on the voltage level of the energy system to be incorporated. Low energy agriculture application could apply a low voltage electrification system since the load requirement is small such as for herbicide spraying (Azwan et al., 2016). Therefore, smaller footprint carrier or machinery, that is installed with the sufficient energy generation capacity could be deployed rather than to utilise bigger size tractor or vehicle. As comparative purposes, Table 1 indicates the advantages and disadvantages of the current technologies available for herbicide spraying in oil palm plantations.

Table 1. Available mechanised herbicide spraying technologies in oil palm plantation (Ludin et al., 2014).

\begin{tabular}{|c|c|c|c|}
\hline $\begin{array}{l}\text { Available } \\
\text { Technology }\end{array}$ & Description & Advantage & Disadvantage \\
\hline $\begin{array}{c}\text { Knapsack sprayer } \\
\text { i }\end{array}$ & $\begin{array}{l}\text { - Hand-lever operated } \\
\text { sprayer with } 16 \text { to } 18 \\
\text { litres capacity tank. } \\
\text { - Coverage up to 1- } \\
2 \text { ha per day per } \\
\text { operator. }\end{array}$ & $\begin{array}{l}\text { - Very cheap } \\
\text { - Could be employed } \\
\text { in various terrain } \\
\text { condition. } \\
\text { - Able to utilise } \\
\text { control droplet } \\
\text { applicator. }\end{array}$ & $\begin{array}{l}\text { - Low coverage and } \\
\text { high operational cost } \\
\text { per area. } \\
\text { - Intensive labour } \\
\text { requirement. } \\
\text { - Hazardous handling } \\
\text { of the chemical. }\end{array}$ \\
\hline
\end{tabular}




\begin{tabular}{|c|c|c|c|}
\hline $\begin{array}{l}\text { Spraying system on-board } \\
\text { utility type vehicle }\end{array}$ & $\begin{array}{l}\text { - Spraying system on- } \\
\text { board the utility type } \\
\text { vehicle that is using } \\
\text { additional internal } \\
\text { combustion engines } \\
\text { for the operation } \\
\text { with a capacity of } \\
\text { 300-400L water. } \\
\text { Average coverage is } \\
\text { about 7-10ha per } \\
\text { day per machine. }\end{array}$ & $\begin{array}{l}\text { - Could be mobilised } \\
\text { at a terrace or } \\
\text { undulating } \\
\text { topography. } \\
\text { - A high-pressure } \\
\text { pump powered by a } \\
\text { petrol engine could } \\
\text { extend the hose to } \\
\text { about } 20 \text { metres } \\
\text { from the vehicle. }\end{array}$ & $\begin{array}{l}\text { - Requires } 2 \text { to } 3 \\
\text { workers for the } \\
\text { operation. } \\
\text { - Unable to utilise a } \\
\text { low volume type } \\
\text { nozzle. } \\
\text { - Difficult to control } \\
\text { water pressure for } \\
\text { both flanks. }\end{array}$ \\
\hline $\begin{array}{l}\text { Tractor mounted spraying } \\
\text { system }\end{array}$ & $\begin{array}{l}\text { Various spraying } \\
\text { methods that usually } \\
\text { employ spraying } \\
\text { boom with low } \\
\text { volume nozzle. } \\
\text { More than 600L of } \\
\text { water could be } \\
\text { carried at a time. }\end{array}$ & $\begin{array}{l}\text { - } \begin{array}{l}\text { Higher coverage of } \\
\text { about 30-50ha per } \\
\text { day. }\end{array} \\
\text { - } \begin{array}{l}\text { Less } \\
\text { requirement. }\end{array} \\
\text { - labour } \\
\begin{array}{l}\text { Able to } \\
\text { sensors utilise } \\
\text { electronic } \\
\text { measurement. }\end{array}\end{array}$ & $\begin{array}{l}\text { - Very high capital } \\
\text { cost. } \\
\text { - Can only be utilised } \\
\text { in a flat area } \\
\text { topography only. } \\
\text { - High maintenance } \\
\text { cost for spraying } \\
\text { system. }\end{array}$ \\
\hline
\end{tabular}

Electrification of the farm implements would also ensure less wastage to the farm input and provides significant productivity. A farm utility vehicle with sufficient power generation capability could embrace the advantages of the system. Thus, the sustainability of agriculture production, in general, is improving by balancing its input-output energy and decreasing its energy intensity (T. Li et al., 2016). One of the systems that enables sufficient energy generation in a smaller footprint farm vehicle is the hybrid power system, where two or more sources of power are available.

Adopting hybrid power technology for a particular agriculture application provides advantages such as higher field coverage, improves the functionality of work, reduces fuel consumption and a few others (Llorens et al., 2010). Besides, a hybrid power farm vehicle could also incorporate a renewable energy source to recharge the battery. The method allows the system to be more versatile and robust (Y. Li et al., 2019).

Solar energy technology on-board a farm vehicle in Malaysia can provide at least $25 \%$ of the energy to power an agriculture electric vehicle (Azwan et al., 2017) for an oil palm plantation operation. It is due to the fact that Malaysia receives about 4,000 to $5,000 \mathrm{~W} / \mathrm{m}^{2}$ average solar irradiance and average sunshine duration between 4 to 8 hours a day (Daut $e t$ $a l ., 2012)$. However, solar is not suitable to be used as a primary energy source in agriculture machinery application since only $20 \%$ to $35 \%$ energy from the sun can penetrate the palm canopies or a broadleaf tree in Malaysia (Shahidan \& Salleh 2007). Thus, making solar energy only as an opportunity source to charge the battery. 
This study aims to analyse the performance of low-level electrification of agriculture implement on a lightweight and small footprint utility vehicle for herbicide spraying in oil palm plantation. The study comprises simulation assessment and a field trial. The simulation is conducted to assess energy generation and utilisation on the hybrid power system vehicle by using the HOMER software. The field assessment is carried out to validate the simulation result.

\section{Materials and Methods}

\subsection{Hybrid power utility vehicle for herbicide spraying}

A three-wheeled utility farm vehicle was fabricated to assemble the proposed system, as depicted in Figure 1. The prototype comprised a 7HP air-cooled diesel power engine, belted continuous variable transmission system, 20Watt solar photovoltaic and other auxiliaries. The diesel-powered machine with an electric starter and rectifier generator was selected since the power is adequate to cater for a proposed gross load of $400 \mathrm{~kg}$ based on the free force analysis (Azwan et al., 2017). The chassis of the three-wheeled utility vehicle was selected since the vehicle concept is widely used in Malaysian oil palm plantation operation (Awaludin et al., 2015) and provides low cost of development. Another factor to consider in the development of the new farm utility vehicle chassis in this study was its weight consideration since the performance of the vehicle also depends on the engine capacity and its gross weight. Thus, a new chassis was developed and fabricated in consideration of those factors.

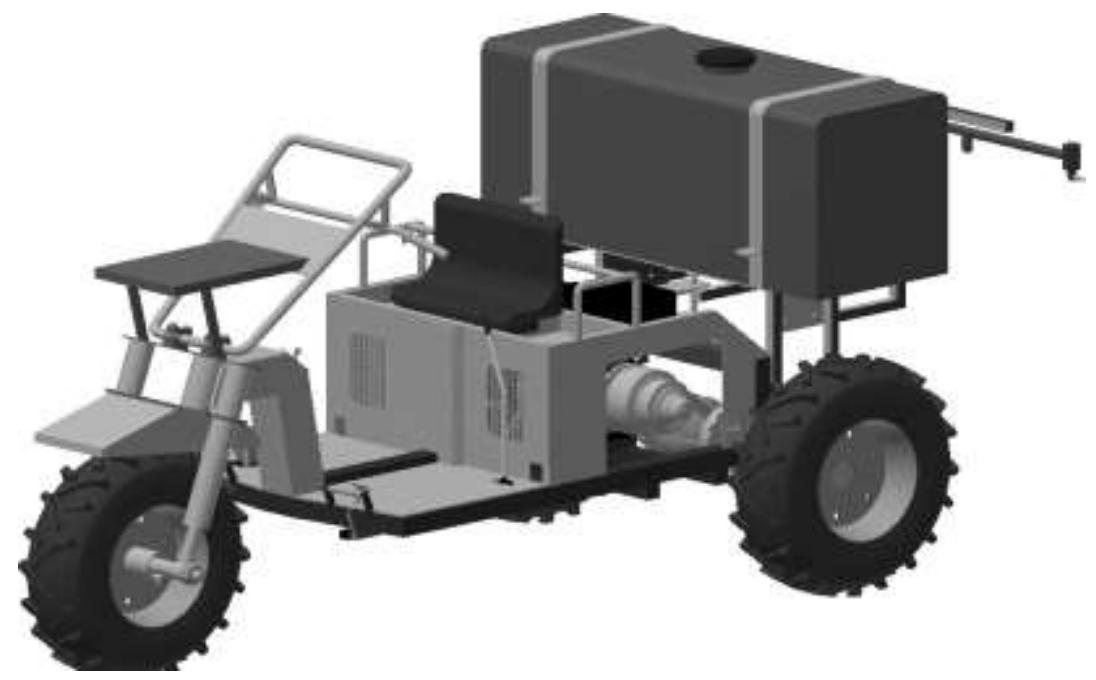

Figure 1. Three-wheel type machine with a solar charging and electric spraying system.

Another function to be incorporated in the prototype was the electrical spraying system. The system consists of a $12 \mathrm{~V}$ electrical pump system, the water tank, the nozzles and also its auxiliaries. The diaphragm pump is activated by a handle switch together with electric solenoids for left or right nozzle selection. A pressure reduction system is also incorporated 
at the spray boom to ensure the correct pressure enters the nozzles for higher spraying performance.

\subsection{HOMER Software simulation}

This study utilised the software developed by the United States National Renewable Energy Laboratory in simulating the energy generation and consumption based on input provided to the software. The software provides significant simulation results such as optimisation of the configuration, capacity of the energy generation for the intended application, and the techno-economic analysis of the system (Azwan et al., 2017). The input data and design are discussed as follows:

\subsubsection{System configuration and Solar energy resources}

Figure 2 depicts the schematic diagram of the proposed design. A DC-bus provides $12 \mathrm{~V}$ system configuration where solar and generator are the power sources and backed-up by a battery to provide a load for spraying application. However, both power sources are also required to recharge the cell by the excess power available. The battery is also needed to provide some energy for engine cranking. About 20amp current is required for cranking purposes, but the use is only on the instantaneous second and it was suggested to ignore for this simulation since the actual energy consumed for this particular application was hard to predict.

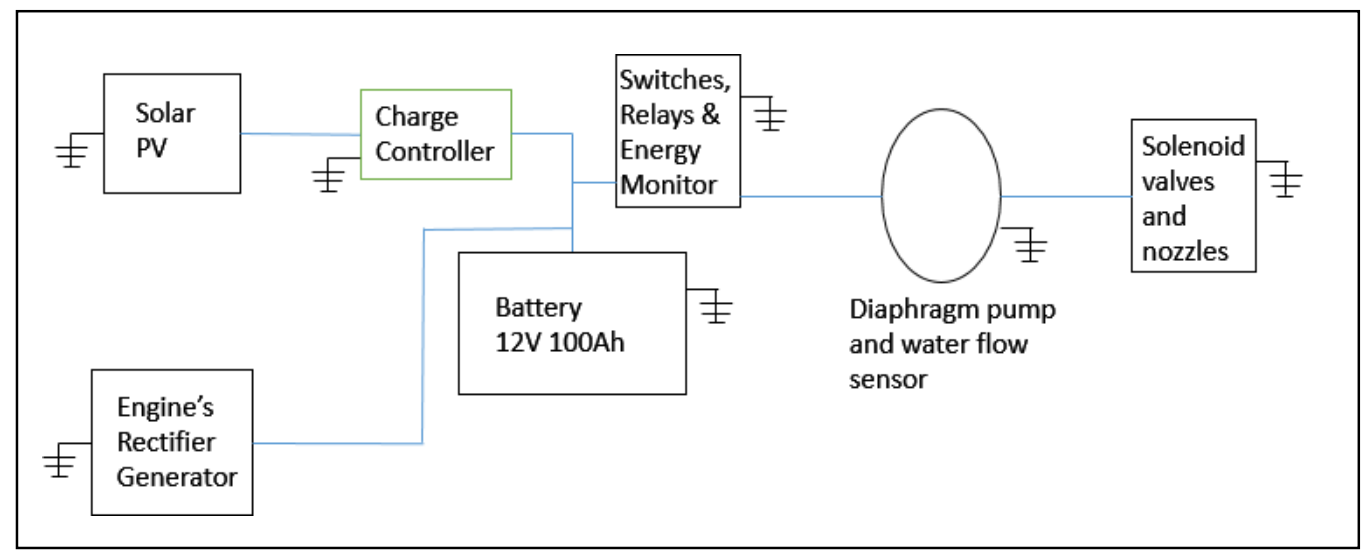

Figure 2. Schematic diagram of the proposed spraying system.

In HOMER, the energy was also investigated based on the baseline data. In this analysis, the solar power was referred from a previous study conducted on the integration of PV onboard EV in oil palm plantation operation (Azwan et al., 2017). Figure 3 depicts the solar energy resource availability based on sky clearness index and daily radiation. 


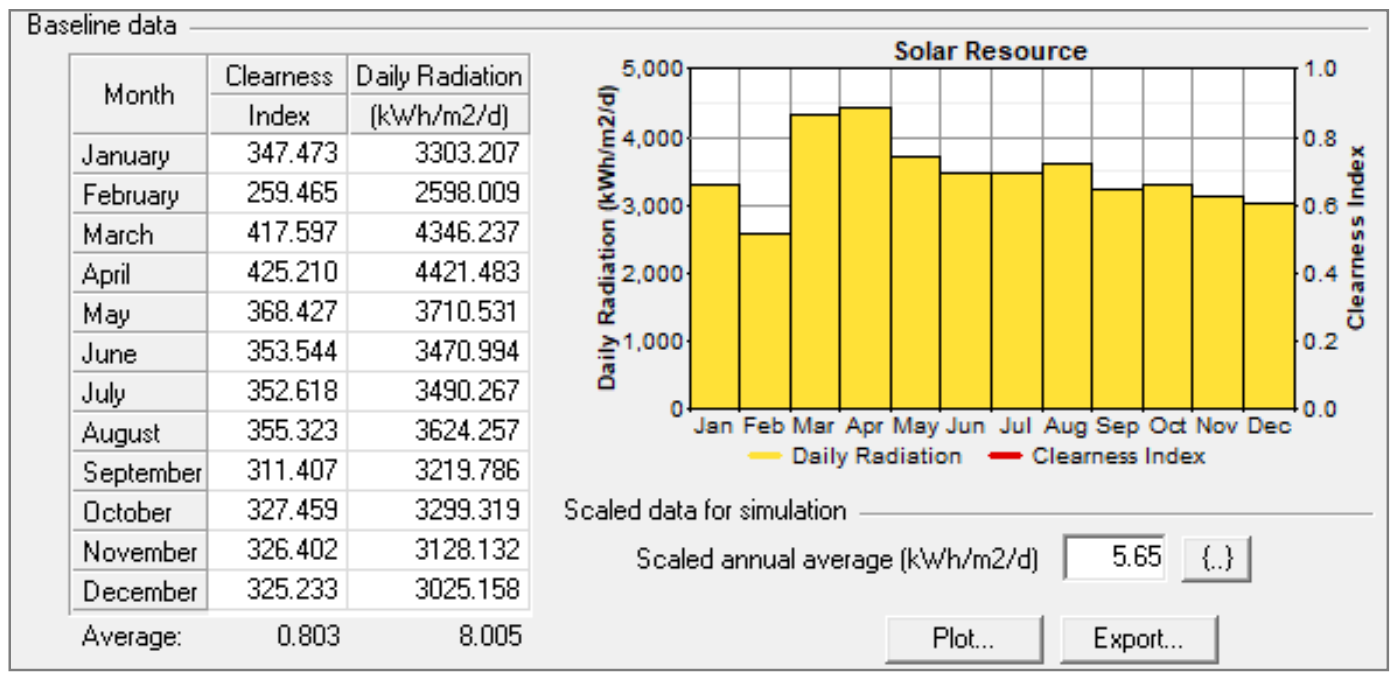

Figure 3. Solar energy resource availability based on sky clearness index and daily radiation.

\subsubsection{Energy for spraying and system constraint}

The assumption of electric spraying load is depicted in Figure 4. The previous study indicated that 138 200L water tank with chemical mixing and 150L per ha nozzle volume could complete a task within 40 to 50 minutes. The vehicle was required to return to the water source after the water depleted in the tank for refilling and mixing process. Therefore, it was assumed in the worst-case scenario that each spraying time is one hour and another one hour for refilling and mixing.

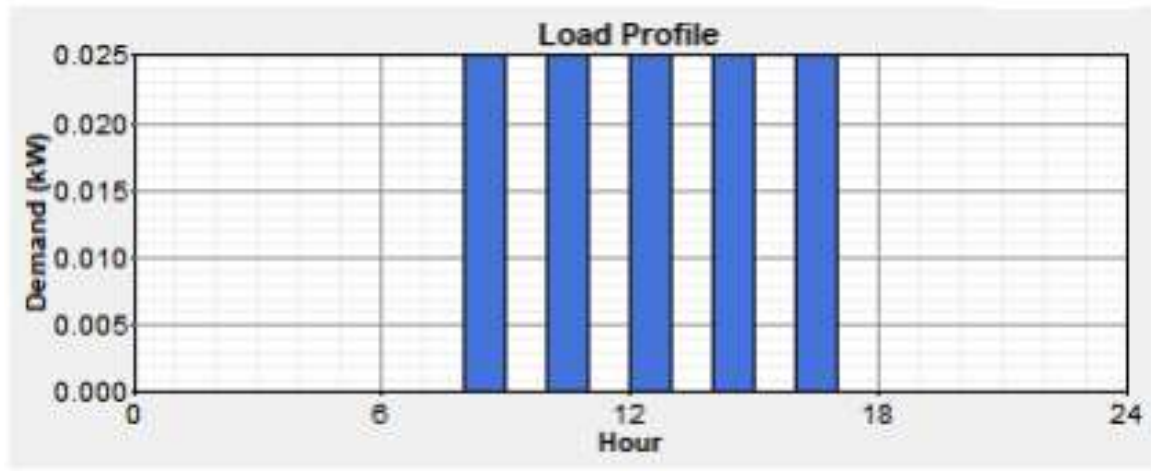

Figure 4. Assumption of the spraying load.

A medium pressure of up to 5 bars of a $12 \mathrm{~V}$ electric diaphragm pump is attached to the system that provides spraying through two sets of low rate spraying nozzles. In terms of energy consumption of an electric sprayer, a small power utilisation about $22 \mathrm{~W}$ on average was observed from a preliminary power test in a laboratory. The result of the test is depicted in Figure 5 and also indicated a variation of spraying rate between $2.25 \mathrm{~L} / \mathrm{m}$ to $2.40 \mathrm{~L} / \mathrm{m}$ due to diaphragm pump characteristic and with 1.5 bar pressure limitation by the pressure 
regulator. The data were recorded by using a wattmeter and logged to a computer. Therefore, an average of $25 \mathrm{Watt}$ power was assumed to be used for the spraying system, as indicated in Figure 4.

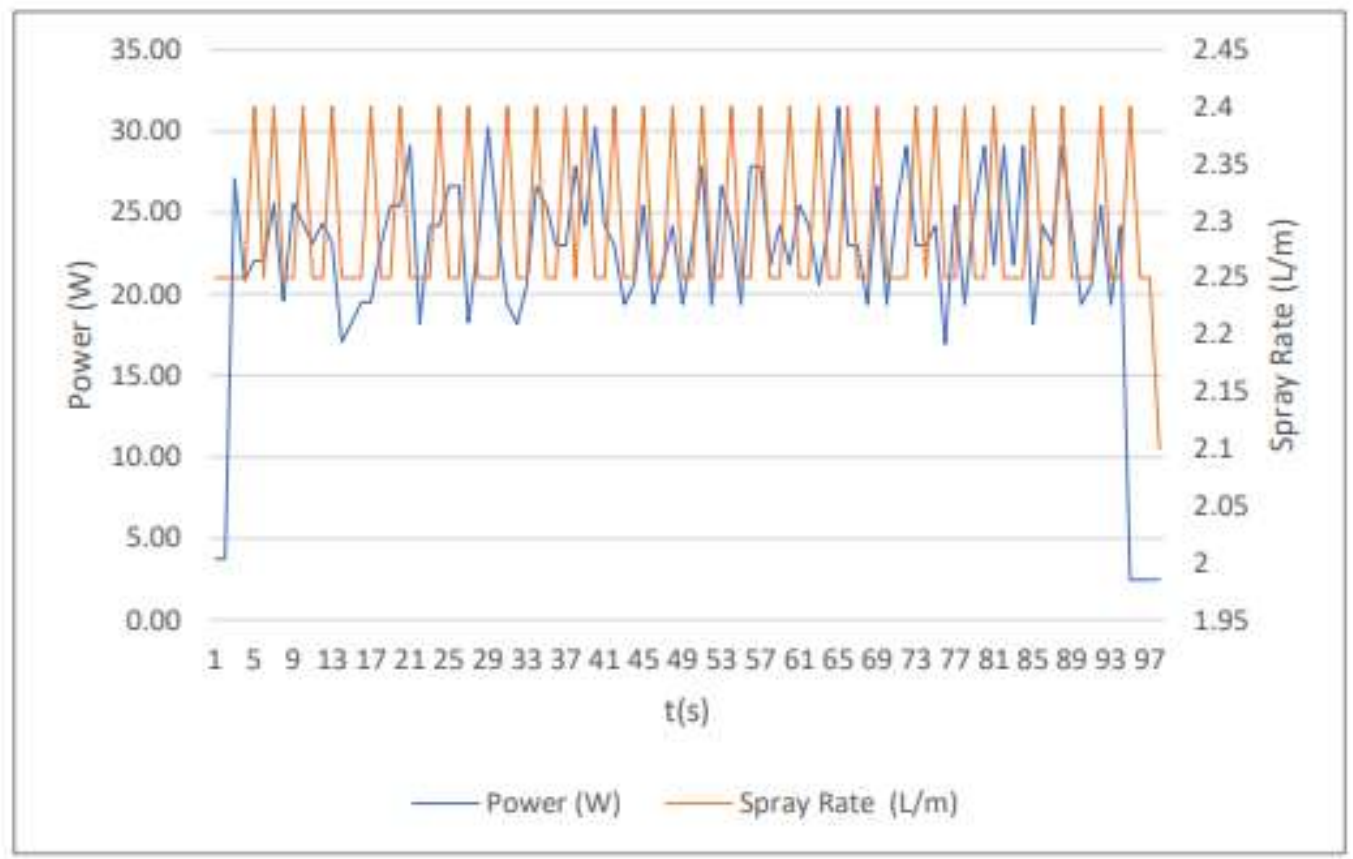

Figure 5. Preliminary energy test for spraying load with 1.5 bar nozzle pressure.

\subsection{In-Field Test and validation}

A study on the prototype performance in the actual field was carried out in a real oil palm plantation in Malaysia. The test period was about two months, from early May to the end of June 2018. The study was conducted in such a way that the prototype carried out a real task of herbicide spraying. A field contractor had been given the job by the estate's management to utilise the prototype and fed the necessary information. The information was the battery state of charge (SoC) and the productivity of the spraying activity. The analysis of battery performance was based on Equation 1 (Vermaak \& Kusakana, 2014).

DoD $=$ SoCfinal - SoCinitial $($ Equation 1$)$

Where;

DoD is referred to as the depth of discharge $(\%)$.

SoCinitial is referred to as the reading of the state of charge (\%) before the activity is carried out. SoCfinal is referred to as the reading of the state of charge (\%) after the activity is completed. 
Battery performance is also related to the efficiency of the energy generator. The impact of solar panel efficiency is very much dependent on the intensity of the solar radiation strike on the solar panel (Rajput \& Sudhakar, 2013) and characteristic of the solar panel itself as depicted in Equation 2. However, for the solar photovoltaic application on-board a vehicle, the solar radiation is varied mostly due to the movement of the vehicle. In a recent study of photovoltaic system on-board an electric vehicle, about $21 \%$ of solar energy can be captured for the application in an oil palm plantation in Malaysia (Azwan et al., 2017). Meanwhile, for the electrical power obtained from a combustion engine vehicle, the efficiency of the rectifier generator is impacted by the crankshaft speed, drop voltage and leakage current. Thus, the effectiveness of both energy generators can be investigated through a state of charge reading in general and later could be compared to the environmental data available.

$$
\begin{aligned}
& \left.\mathrm{r}=\frac{\text { VOC } \times \text { Isc }}{\text { A x I }} \text { X } 100 \% \quad \text { (Equation } 2\right) \\
& \text { Where: } \\
& \mathrm{r} \quad=\text { solar panel efficiency }(\%) \text { Voc= open circuit voltage } \\
& \text { Isc = short circuit current } \\
& \text { A = total solar panel area }\left(\mathrm{m}^{2}\right) \\
& \mathrm{I}=\text { average intensity of the solar radiation }\left(\mathrm{W} / \mathrm{m}^{2}\right)
\end{aligned}
$$

\section{Results and Discussion}

\subsection{Simulation Analysis}

HOMER software has provided significant simulation results, as depicted in Figure 6. The results obtained indicate that the highest energy fraction between solar power and engine rectifier output to serve the load is the renewable energy or solar energy up to $70 \%$. The results also indicate that no energy shortage occurred, thus making the herbicide spraying feasible for this experimental setup. Further simulation analysis on battery's state of charge (SoC) versus DC primary load or spraying power as depicted in Figure 7 also shows that battery is always in the optimum percentage at capacity between 0.02 to $0.025 \mathrm{~kW}$. The depth of discharge is not more than $20 \%$ of its original state. The condition will ensure longer battery life or it is less damaging to battery health (Abdelhamid, Singh \& Haque, 2012; Doerffel \& Sharkh, 2006). Good battery condition will ensure this practice could be accepted and used substantially in the plantation. Besides, the approach could also promote sustainable development in agriculture. More advanced agriculture tools with sensors and 
microprocessor could also later be incorporated into the system since the electrification platform is available.

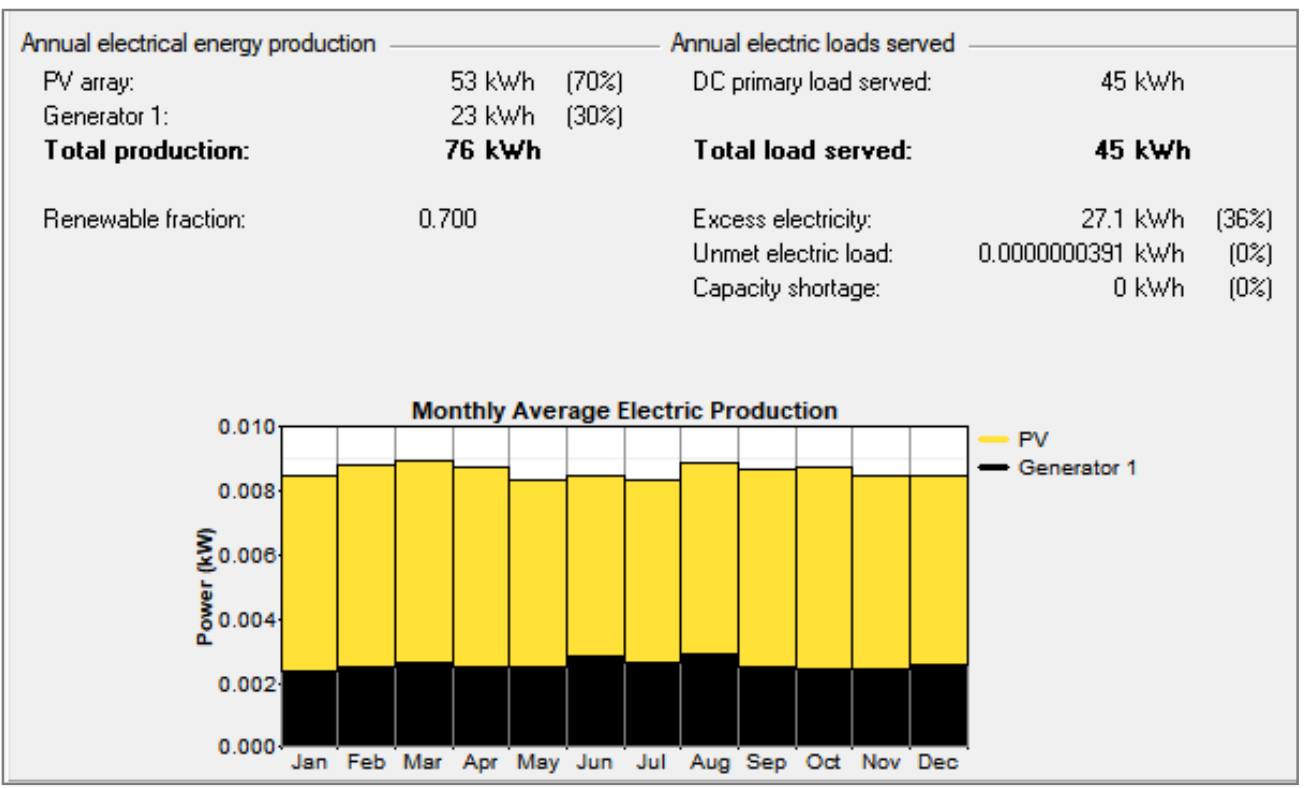

Figure 6. Result of the Simulation Analysis from HOMER interface.

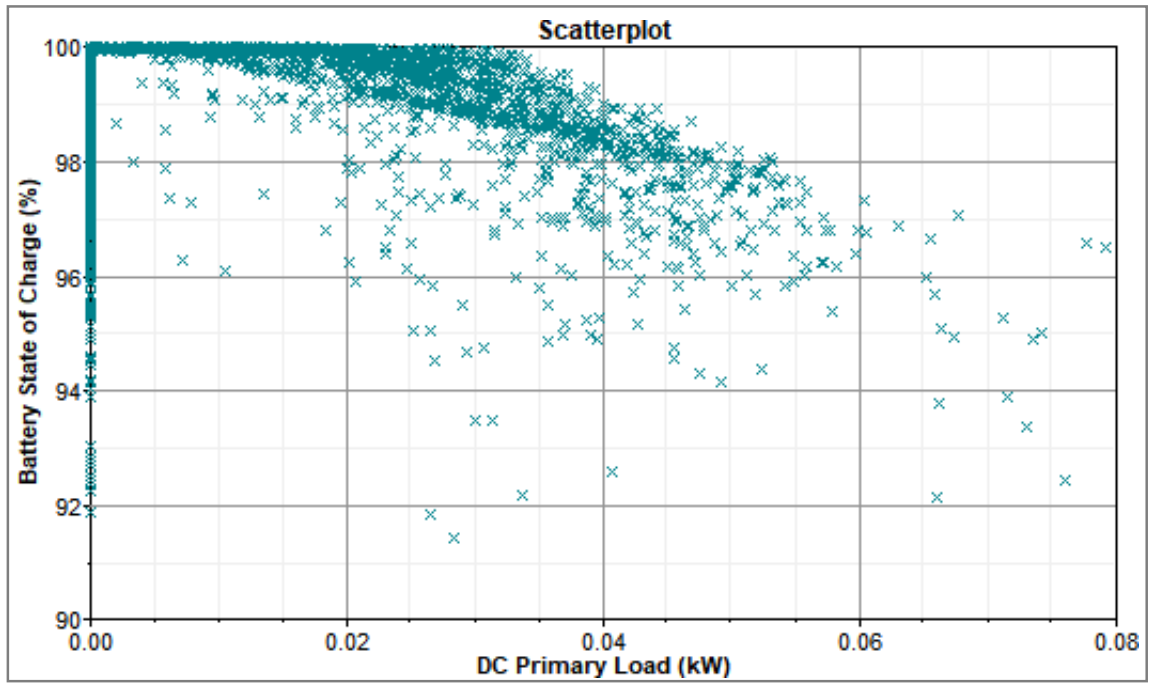

Figure 7. HOMER simulation result of soc vs. DC primary load or the spraying power.

In terms of economic analysis, HOMER had produced two optimisation results, as shown in Table 2, where both scenarios refer to the energy system with different equipment and sizing to serve the spraying load indicated previously. HOMER analysed the economic based on the input provided to the software. Table 3 indicates the economic assumption used for the analysis in Scenario 1 that certain parameters were quoted from previous studies. Scenario 1 comprised of energy equipment with $20 \mathrm{~W}$ solar photovoltaic and $60 \mathrm{~W}$ rectifier engine 
output. Meanwhile, Scenario 2 is the energy system without solar photovoltaic and bigger size rectifier engine output of $100 \mathrm{~W}$. The capacity of rectifier engine output is more significant in Scenario 2 due to its massive size. Thus, it incurred slightly higher capital cost. Both scenarios utilised cost of diesel that is capped at RM2 per litre. The analysis shows that the price of energy for Scenario 1 was almost $70 \%$ lower as compared to Scenario 2. The result validates the previous study, which is $70 \%$ of the energy for electric spraying load is provided by solar energy. Thus, less diesel fuel was used in Scenario 1 that provided high impact to the energy cost.

Table 2. Optimisation result of system selection. 246

\begin{tabular}{ccccc}
\hline & $\begin{array}{c}\text { Solar Energy } \\
\text { Power }\end{array}$ & $\begin{array}{c}\text { Rectifier Engine } \\
\text { Output }\end{array}$ & $\begin{array}{c}\text { Initial Capital } \\
\text { (RM) }\end{array}$ & $\begin{array}{c}\text { Cost of Energy } \\
(\mathbf{R M} / \mathbf{k W h})\end{array}$ \\
\hline Scenario 1 & $20 \mathrm{~W}$ & $60 \mathrm{~W}$ & $3,100^{1}$ & 37.64 \\
\hline Scenario 2 & 0 & $100 \mathrm{~W}$ & $5,000^{1}$ & 106.00 \\
\hline
\end{tabular}

*The cost quoted by the equipment supplier.

Table 3. Economic assumption for the selected optimisation result (Azwan et al., 2017; Jorgensen, 2008;

Vermaak \& Kusakana, 2014).

\begin{tabular}{lll}
\hline SYSTEM & DETAILS & ASSUMPTION \\
\hline Solar Photovoltaic & Capital & $200 \mathrm{RM}$ \\
20Watt & Operational \& maintenance & 0 \\
& Lifetime & 5 years \\
\hline Battery & Capital & $800 \mathrm{RM}$ \\
12V 100Ah & Operational \& maintenance & 300RM/year \\
\hline Engine Rectifier & Capital & $2,000 \mathrm{RM}$ \\
60Watt & Operational \& maintenance & $0.6 \mathrm{RM} / \mathrm{hour}$ \\
& Fuel consumption & $0.25 \mathrm{RM} / \mathrm{L} / \mathrm{hour}$ \\
\hline
\end{tabular}

\subsection{In-Field Test Validation}

The test was carried out in an actual oil palm plantation with herbicide spraying operation carried out based on the machine setup explained previously. The experiment was carried out to validate the simulation result. The actual field test was conducted within two months, with almost 150 ha of the area covered.

Battery condition was monitored through the state of charge (SoC) meter. The operator logged the battery SOC before and after the work completed daily on the farm. The area covered for the daily operation was also recorded based on the estate's map provided.

The result, as Figure 8 shows that the battery was always in good condition since the depth of discharge (DoD) was in the range of $20 \%$ only. The percentage was obtained by subtracting SoC after the work completed with SoC before the work started, as stated in Equation 1. It indicates that the proposed setup enables the battery to be charged and 
discharged effectively. The result is also consistent with the HOMER simulation result, where battery SoC usually felt up to only $20 \%$ of its original state as depicted in Figure 7.

The DoD is always dependent on the battery consumption in undertaking the fieldwork such as herbicide spraying. Besides that, initial battery condition also determines the SoC reading since lower initial battery voltage will result in higher current flow to achieve the desired power and subsequently increase the energy consumption since the current flow is also associated with more heat generated. Thus, one method to improve stability of the DoD is to ensure the battery voltage is at the optimum level before any work is carried out. In terms of machine productivity, it was found that on average, 8ha per day of the area can be covered for herbicide spraying activity. The result shows significant productivity as compared to the manual labour of only 1-2 ha per day per operator and almost similar productivity with the existing spraying technology employed in the field, where the pressure water is pumped through a secondary fossil fuel engine (Ludin et al., 2014).

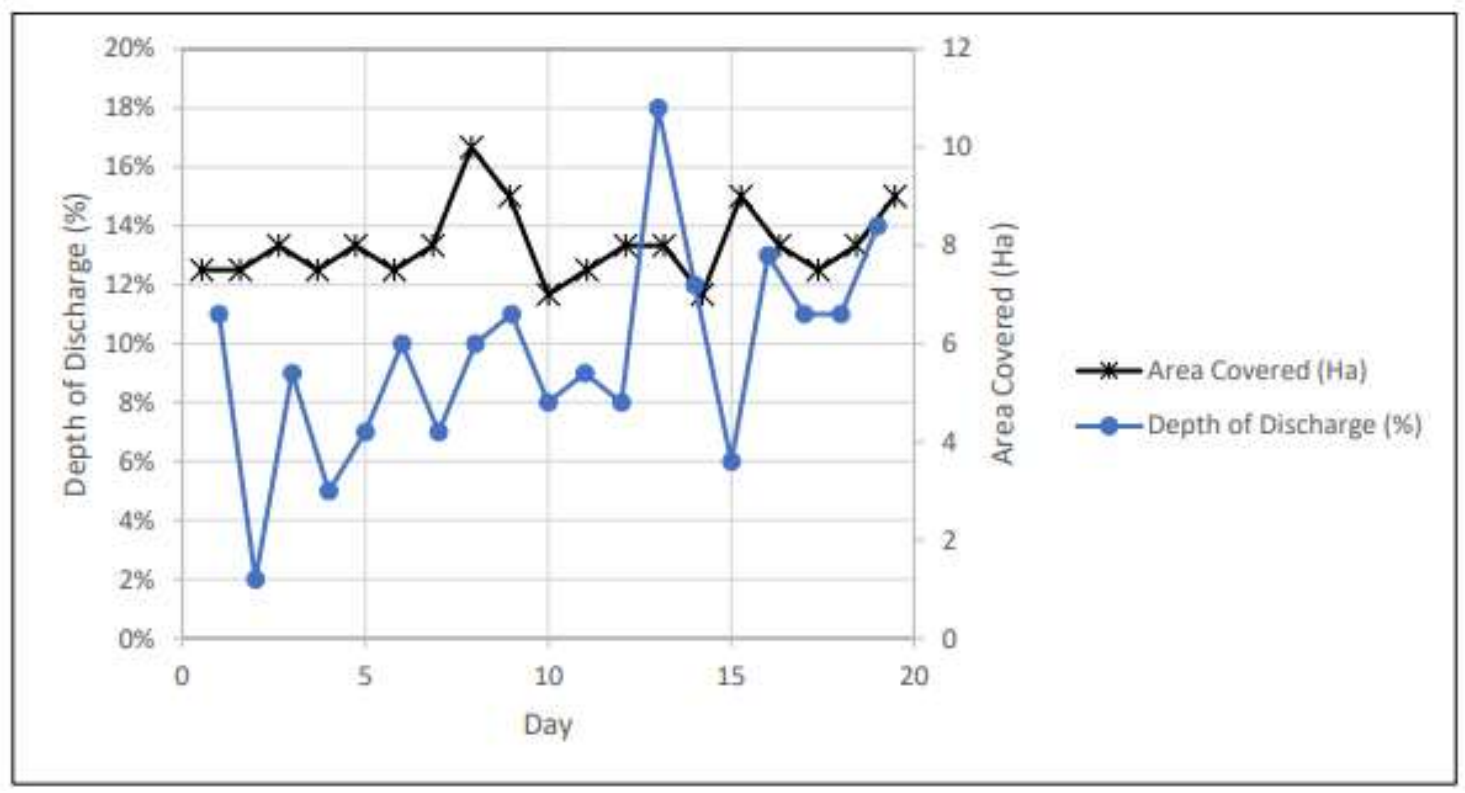

Figure 8. Results of the field validation (depth of discharge and area covered).

\section{Conclusion}

In general, the study indicates that renewable energy and energy efficiency technology is feasible to be incorporated into a mechanised oil palm plantation operation. The simulation result shows that renewable energy power fraction is almost $70 \%$ for the use of an electric medium pressure pump for herbicide spraying in the field. The analysis also indicates excellent battery performance in terms of the state of charge condition throughout the year. Reduction of fossil fuel utilisation of more than $70 \%$ will increase the sustainability of the farm operation. The simulation analysis by using HOMER also indicates the cost of energy is lower for the system proposed as compared to the full diesel fuel engine utilisation as the 
primary energy for the herbicide spraying power. The lower energy cost is due to the smaller engine and photovoltaic system requirement. Besides that, the actual field test has validated the simulation analysis results and system performance. The test indicated that the system could work continuously and produce a significant effect in terms of productivity, which was about 8ha per day with a single man operation. The function of the hybrid power utility vehicle concept could be expanded to other farm tasks and definitely could improve the sustainability of the oil palm mechanisation operation.

Acknowledgement: The researchers would like to thank the management of MPOB, especially the Director-General of MPOB in supporting the research and granting permission for this publication.

Funding: MPOB funded this research under PAC Project allocation BD433-2015, Hybrid Power Vehicle for Herbicide Spraying.

Conflicts of Interest: The authors declare no conflict of interest for publication of the manuscript.

\section{References}

Abdelhamid, M., Rhodes, K., Christen, E., et al. (2018). Analysis and opportunities for solar photovoltaics technologies on electrified vehicles. SAE Technical Papers, doi:10.4271/2018-01-0426

Abdelhamid, M., Singh, R. \& Haque, I. (2012). Role of PV generated DC power in transport sector: Case study of plug-in EV. Renewable Energy, 16(1), 1-7. doi:10.1016/j.rser.2010.07.062

Awaludin, A., Salim, S., Salim, S., et al. (2015). Performance study of an oil palm fresh fruit bunch three wheeler evacuation machine. The Online Journal of Science and Technology, 5(2), 46-53.

Azwan, M. B., Ludin, N. A., Abd Rahim, S., et al. (2016). Analysis of energy utilisation in Malaysian oil palm mechanisation operation. Journal of Oil Pam Research, 485-495.

Azwan, M. B., Norasikin, A. L., Sopian, K., et al. (2017). Assessment of electric vehicle and photovoltaic integration for oil palm mechanisation practise. Journal of Cleaner Production, 140, 1365-1375. doi:10.1016/j.jclepro.2016.10.016

Blackmore, B. S., Wang, M. \& Runov, B. (2005). Robotic agriculture - the future of agricultural mechanisation?. 5th European Conference on Precision Agriculture, 621-628. Uppsala, Sweden: Wageningen Academic Publishers.

Daut, I., Zainuddin, F., Irwan, Y. M., et al. (2012). Analysis of solar irradiance and solar energy in Perlis, northern of peninsular Malaysia. Energy Procedia, 18, 1421-1427. doi:10.1016/j.egypro

Rajput, D. S. \& Sudhakar, K. (2013). Effect of dust on the performance of PV panels. International Journal of ChemTech Research, 5(2), 1083-1086.

Doerffel, D. \& Sharkh, S. A. (2006). A critical review of using the Peukert equation for determining the remaining capacity of lead-acid and lithium-ion batteries. Journal of Power Sources, 155(2), 395-400. doi:10.1016/j.jpowsour.2005.04.030

Jorgensen, K. (2008). Technologies for electric, hybrid and hydrogen vehicles: Electricity from renewable energy sources in transport. Utilities Policy, 16(2), 72-79. doi:10.1016/j.jup.2007.11.005

Kushairi, A., Singh, R. \& Ong-Abdullah, M. (2017). The oil palm industry in Malaysia: Thriving with transformative technologies. Journal of Oil Palm Research, 29(4), 431-439. doi:10.21894/jopr.2017.00017

Li, T., Baležentis, T. \& Makutėnienè, D., et al. (2016). Energy-related CO2 emission in European Union agriculture: driving forces and possibilities for reduction. Applied Energy, 180, 682-694. doi:10.1016/J.APENERGY.2016.08.031

Li, Y., Huang, X., Liu, D., et al. (2019). Hybrid energy storage system and energy distribution strategy for four-wheel 
independent-drive electric vehicles. Journal of Cleaner Production, 220, 756-770. doi:10.1016/j.jclepro.2019.01.257

Llorens, J., Gil, E., Llop, J., et al. (2010). Variable rate dosing in precision viticulture: Use of electronic devices to improve application efficiency. Crop Protection, 29(3), 239-248. doi:10.1016/j.cropro.2009.12.022

Ludin, N. A., Bakri, M. A. M., Kamaruddin, N., et al. (2014). Malaysian oil palm plantation sector: Exploiting renewable energy toward sustainability production. Journal of Cleaner Production, 65, 9-15. doi:10.1016/j.jclepro.2013.11.063

Shahidan, M. F. \& Salleh, E. (2007). Effects of tree canopies on solar radiation filtration in a tropical microclimatic environment. PLEA2007 - The 24th Conference on Passive and Low Energy Architecture, 400-406.

Somà, A. (2017). Trends and hybridization factor for heavy-duty working vehicles. Hybrid Electric Vehicles. doi:10.5772/intechopen.68296

Vermaak, H. J. \& Kusakana, K. (2014). Design of a photovoltaic-wind charging station for small electric Tuk-tuk in D.R.Congo. Renewable Energy, 67, 40-45. doi:10.1016/j.renene.2013.11.019 